\title{
Serpulid communities from two marine caves in the Aegean Sea, eastern Mediterranean
}

\author{
ROSSANA SANFILIPPO ${ }^{1}$, ANTONIETTA ROSSO ${ }^{1}$, ADRIANO GUIDO ${ }^{2}$ AND VASILIS GEROVASILEIOU \\ ${ }^{1}$ Department of Biological, Geological and Environmental Sciences, University of Catania, Corso Italia, 57, I-95129 Catania, Italy, \\ ${ }^{2}$ Department of Biology, Ecology and Earth Sciences, University of Calabria, Via Bucci, cubo 15b, I-87036 Rende, Cosenza, Italy, \\ ${ }^{3}$ Institute of Marine Biology, Biotechnology and Aquaculture, Hellenic Centre for Marine Research, 71500 Heraklion, Crete, Greece
}

\begin{abstract}
This paper is a first detailed contribution to the knowledge of serpulid diversity from marine caves of the eastern Mediterranean Sea. A total of 27 taxa were recorded in two submerged caves of Lesvos Island, in the Aegean Sea. A clear trend of variability was observed with serpulid abundance, specifically that of sciaphilic and deep-sea species, increasing inwards while the number of taxa and species diversity did not change significantly across the two caves. In the innermost sectors of the studied caves two types of bioconstructions were observed: (a) 'coiled doughnuts' of Protula, recorded for the first time in Mediterranean caves; and (b) 'biostalactites' mainly consisting of skeletal metazoans recorded for the first time from the eastern Mediterranean. The results of the present study revealed new faunal elements and type of bioconstructions for the Mediterranean marine caves, showing that several aspects of their communities are still poorly known and deserve to be further investigated.
\end{abstract}

Keywords: Annelida, Serpulinae, Spirorbinae, tubeworms, bioconstructions, biostalactites, cave-dwellers, biodiversity, colonization pattern, Holocene

Submitted 1 November 2016; accepted 16 February 2017; first published online 23 March 2017

\section{INTRDDUCTION}

Marine caves are characterized by environmental gradients generating spatial variability of sessile colonizers (Harmelin, 1985, 1986; Bianchi \& Morri, 1994; Bussotti et al., 2006). These complex habitats constitute 'biodiversity reservoirs' of high conservation value, harbouring endemic species and 'ancient' forms (Bianchi et al., 2012; Gerovasileiou \& Voultsiadou, 2012). Although Mediterranean marine cave communities have been the subject of research in several studies, considerable knowledge gaps still exist, with regard to certain regions (e.g. eastern and southern Mediterranean sectors) and taxonomic groups (Gerovasileiou et al., 2015, 2016a).

Serpulid polychaetes are among the dominant sessile taxa in confined marine cave systems (Zibrowius, 1968, 1971; Belloni \& Bianchi, 1982; Bianchi, 1985; Harmelin et al., 1985; Bianchi \& Sanfilippo, 2003), sometimes forming bioconstructions that resemble pseudo-stalactites. Such formations have been observed to date in the Caribbean Sea (Macintyre et al., 1982), the Tyrrhenian Sea in the western Mediterranean (Antonioli et al., 2001) and the southern Adriatic and Ionian seas in the central Mediterranean (Belmonte et al., 2009; Quarta et al., 2010; Sanfilippo et al., 2015).

The diversity of serpulids in marine cave habitats has been investigated mostly in the western Mediterranean Sea (e.g. Zibrowius, 1968; Di Geronimo et al., 1993; Taddei-Ruggiero

Corresponding author:

R. Sanfilippo

Email: sanfiros@unict.it et al., 1996; Bianchi \& Sanfilippo, 2003; Harmelin et al., 2003; Rosso et al., 2013). To date, a total of 51 serpulid species have been reported from Mediterranean marine caves in the literature (V. Gerovasileiou, unpublished data).

The research effort recently invested in marine caves of the eastern Mediterranean has raised the regional biodiversity known from this habitat type (Gerovasileiou et al., 2015). Most studies, however, focused on other taxa, which dominate in marine caves, such as sponges (e.g. Gerovasileiou \& Voultsiadou, 2016). Bailey (1969) recorded eight Spirorbinae species from a small submerged cave in Chios Island (North Aegean Sea) but most serpulid species known from the Aegean ecoregion have been reported from habitats other than caves (Knight-Jones et al., 1991; Koçak et al., 1999; Arvanitidis, 2000; Bianchi \& Morri, 2000; Çınar et al., 2014).

The aim of this paper was to (1) provide a first detailed record of the diversity of serpulids in submerged caves of the under studied eastern Mediterranean; (2) examine the structure of serpulid assemblages in this area, focusing on aspects of their morphology, ecology and growth form; and (3) investigate their distribution patterns along different cave sectors.

\section{MATERIALS AND METHODS}

\section{Study areas}

The surveyed caves are located off Lesvos Island (Aegean Sea, eastern Mediterranean) (Figure 1A). Agios Vasilios cave 
$\left(38.969^{\circ} \mathrm{N} 26.541^{\circ} \mathrm{E}\right)$ is a blind cave located at a depth range of $24-40 \mathrm{~m}$ (Figure $1 \mathrm{~B}$ ). Fara cave $\left(38.969^{\circ} \mathrm{N} 26.477^{\circ} \mathrm{E}\right)$ is $32 \mathrm{~m}$ long and has the shape of a tunnel, ending in a dark chamber connected to a second cave through a fissure (Figure $1 \mathrm{~B}$ ). The entrance of the cave is located at $18 \mathrm{~m}$ while the average depth inside the cave is $14 \mathrm{~m}$. Both caves are formed in Triassic carbonate rocks (Katsikatsos et al., 1982). The two caves were mapped and depicted in three-dimensional models with 'cavetopo' software (Gerovasileiou et al., 2013a). The structure of their sessile communities has been previously described (Gerovasileiou et al., 2013b, 2014; Gerovasileiou \& Voultsiadou, 2016) but their serpulid diversity has not been studied.

\section{Sampling process and sample analysis}

Three replicate quadrats of $400 \mathrm{~cm}^{2}(20 \times 20 \mathrm{~cm})$ were scraped at 10 sampling stations in the surveyed caves (six in Fara cave and four in Agios Vasilios cave) in 2010 by scuba diving using the quadrate sampler designed by Chintiroglou \& Koukouras (1992). Sampling stations (Figure 1B, Table 1) represented different assemblages of the sidewalls and ceiling at different distances from the entrance of the caves. Photographs of serpulid bioconstructions were also taken in situ. Samples were sieved $(0.5 \mathrm{~mm})$ and preserved in $10 \%$ formalin. After the sorting process, serpulids were identified at the species level under a stereomicroscope.

For each station, living communities and thanatocoenoses (empty tubes) were examined, and the serpulid abundance $(\mathrm{N})$, number of taxa (S) and Shannon-Wiener diversity index $\left(\mathrm{H}^{\prime}\right)$ were calculated. Moreover, all taxa were assigned to six ecological groups according to Rosso et al. (2013 and references therein), specifically: (1) 'Cave species' including sciaphilic species which thrive in caves as well as in other cryptic micro-habitats (cavities or crevices); (2) 'Sciaphilic and/or coralligenous species' which show preference for shadowy and sheltered biotopes such as overhangs, coralligenous concretions, and the lower surface of small-sized hard substrata lying on soft bottoms; (3) 'Deep-water species', which are usually found on the outer shelf and upper slope (lower circalittoral and upper bathyal zones); (4) 'Shelf species', including more or less euryoecious species which are widely distributed in shelf environments; (5) 'Shallow-shelf species' including light-tolerant species able to colonize infralittoral to upper circalittoral habitats; (6) 'Unplaced species' which cannot be placed in any of the above groups. The latter group includes species for which no distributional preference is known and taxa identified at high taxonomic levels.

Low magnification images of selected specimens were taken with a Zeiss Discovery V8A stereomicroscope equipped with an Axiocam MRC and Axiovision acquisition system. Specimens are deposited in the Palaeontological Section of the Earth Science Museum at the University of Catania (Italy).

\section{Statistical analysis}

One-way permutational ANOVA (perANOVA) was used in order to investigate the variability of the above biotic measures across the stations of each cave (factor, Station; fixed with six

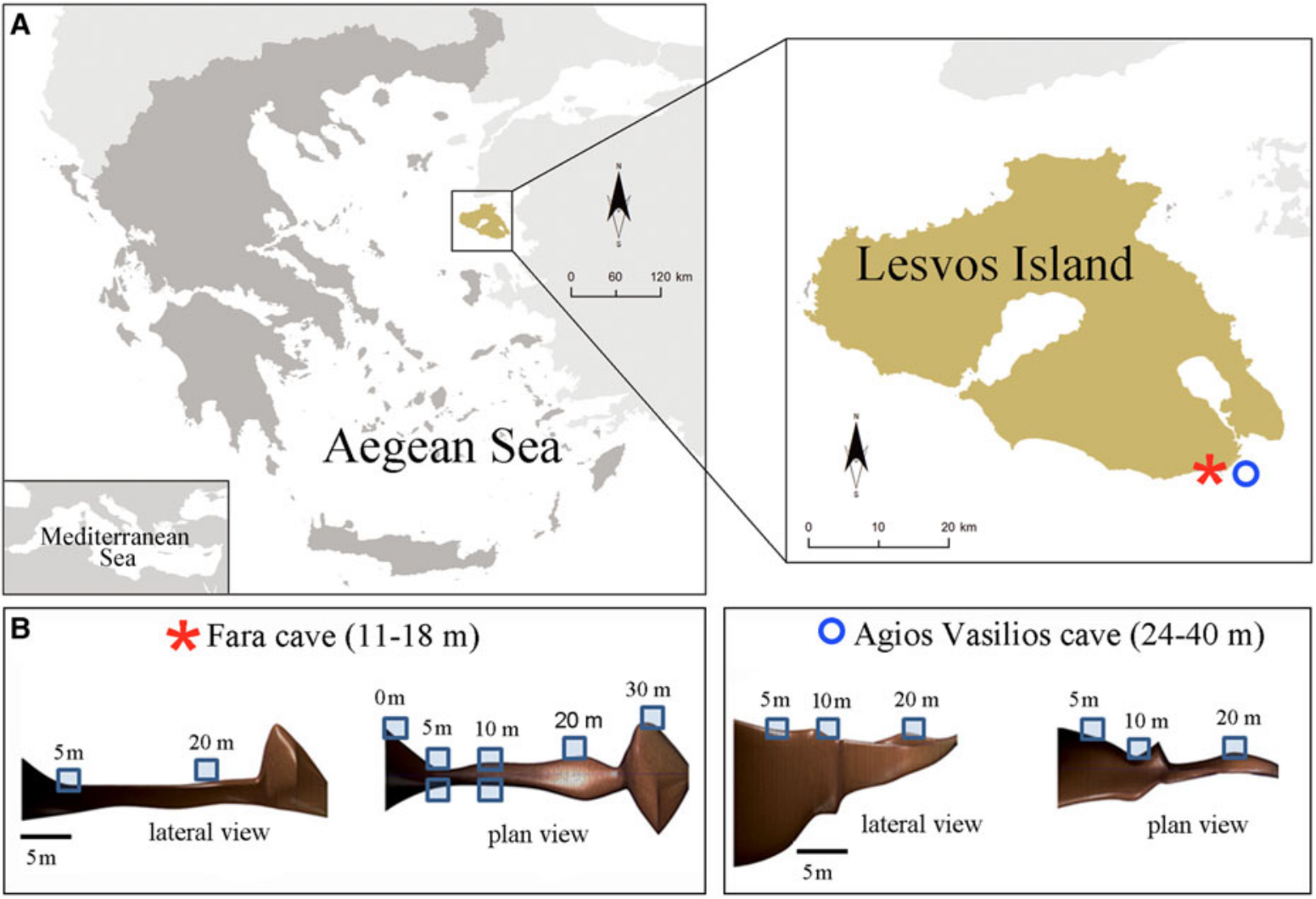

Fig. 1. Map of Lesvos Island in the Aegean ecoregion, showing the locations of the studied caves (A). Scaled three-dimensional depictions (lateral and plan views) of Fara and Agios Vasilios caves produced with 'cavetopo' software (Gerovasileiou et al., 2013a) and location of sampling sites (B). 
Table 1. Description of the sampling sites for all stations (i.e. distance from the entrance and position on the walls of the cave) and their basic community structure (F: Fara cave, V: Agios Vasilios cave).

\begin{tabular}{|c|c|c|}
\hline Stations & Site description & Community \\
\hline $\mathrm{F}_{1}$ & Left wall (vertical), at the cave entrance & Coralligenous community, dominated by calcareous rhodophytes \\
\hline $\mathrm{FC}_{1}$ & Ceiling, $5 \mathrm{~m}$ from the entrance & Semi-dark cave community, dominated by scleractinians and sponges \\
\hline $\mathrm{F}_{2}$ & $\begin{array}{l}\text { Left wall (vertical/positive inclination), covered with a layer of } \\
\text { sediment, 5-10 } \mathrm{m} \text { from the entrance }\end{array}$ & Semi-dark cave community, dominated by sponges \\
\hline $\mathrm{F}_{3}$ & Right wall (overhanging), 5-10 $\mathrm{m}$ from the entrance & Semi-dark cave community, dominated by scleractinians and sponges \\
\hline $\mathrm{FC}_{2}$ & Ceiling, $15-20 \mathrm{~m}$ from the entrance & $\begin{array}{l}\text { Transitional zone between the semi-dark and dark cave community, } \\
\text { dominated by serpulids and bryozoan nodules }\end{array}$ \\
\hline $\mathrm{F}_{4}$ & $\begin{array}{l}\text { Cave walls (vertical), covered with a black coating of Fe-Mn } \\
\text { oxides, } 20-30 \mathrm{~m} \text { from the entrance }\end{array}$ & Dark cave community, dominated by serpulids and sponges \\
\hline $\mathrm{VC}_{1}$ & Ceiling, 5-10 $\mathrm{m}$ from the entrance & Semi-dark cave community, dominated by scleractinians and sponges \\
\hline $\mathrm{V}_{1}$ & Cave walls (vertical), 5-10 $\mathrm{m}$ from the entrance & Semi-dark cave community, dominated by sponges \\
\hline $\mathrm{VC}_{2}$ & Ceiling, $15-20 \mathrm{~m}$ from the entrance & $\begin{array}{l}\text { Dark cave community, dominated by scleractinians, sponges and } \\
\text { serpulids }\end{array}$ \\
\hline $\mathrm{V}_{2}$ & Cave walls (vertical), $15-20 \mathrm{~m}$ from the entrance & Dark cave community, dominated by sponges and serpulids \\
\hline
\end{tabular}

levels for Fara cave and four levels for Agios Vasilios cave). Resemblance of the serpulid community in the different sampling stations of the caves was examined with multidimensional scaling (MDS), based on the Bray-Curtis similarity index (fourth root transformed mean abundance data).

The contribution of serpulid taxa to the similarity of samples within the resulting groups was estimated with SIMPER (SIMilarity PERcentages). Statistical analysis was undertaken using PRIMER-E v6 software package (Clarke \& Gorley, 2006).

\section{RESULTS}

\section{Taxonomic composition}

A total of 27 serpulid taxa were identified in the two caves (19 Serpulinae and 8 Spirorbinae), 21 of which were common in both caves ( 16 Serpulinae and 5 Spirorbinae). Living serpulid assemblages consisted of 14 taxa (10 Serpulinae and 4 Spirorbinae), 6 of which ( 5 Serpulinae and 1 Spirorbinae) were found in both caves (Table 2). The thanatocoenoses

Table 2. Systematic list of serpulid taxa recorded in the studied Aegean caves (bold font indicates a living community).

\begin{tabular}{|c|c|c|c|c|c|c|c|c|c|c|}
\hline & $\mathbf{F}_{1}$ & FC1 & $\mathbf{F}_{2}$ & $\mathbf{F}_{3}$ & FC2 & $\mathbf{F}_{4}$ & VC1 & V1 & $\mathrm{VC}_{2}$ & $\mathbf{V} 2$ \\
\hline \multicolumn{11}{|l|}{ Serpulinae } \\
\hline Serpula cavernicola Fassari \& Mòllica (1991) & & 2 & & 6 & & 4 & 2 & 9 & & 11 \\
\hline 'Serpula vermicularis' Linnaeus, 1767 & 4 & & 2 & & & & & & & \\
\hline Serpula vermicularis f. echinata Linnaeus, 1769 & & & & & & & 3 & 3 & & \\
\hline Serpula concharum Langerhans, 1880 & 2 & $3+2$ & $\mathbf{1}$ & & 4 & & $\mathbf{1}$ & & & \\
\hline Serpula concharum (deep form) Langerhans, 1880 & & & & & & & & 3 & & \\
\hline Spiraserpula massiliensis (Zibrowius, 1968) & & & & & & 6 & & 6 & $10+6$ & \\
\hline Vermiliopsis labiata (O.G. Costa, 1861) & 4 & & & & & 8 & & $7+2$ & 3 & $36+5$ \\
\hline Vermiliopsis sp. & & & 2 & 2 & 2 & & 2 & 1 & 1 & \\
\hline Metavermilia multicristata (Philippi, 1844) & 3 & 3 & $30+8$ & 5 & $16+6$ & $45+4$ & 2 & $20+4$ & $40+3$ & 38 \\
\hline Semivermilia crenata (O.G. Costa, 1861) & & 30 & $58+8$ & 36 & $145+18$ & 185 & $70+12$ & 93 & 78 & 77 \\
\hline Semivermilia pomatostegoides (Zibrowius, 1969) & & & & & 31 & & & & 8 & 8 \\
\hline Filogranula calyculata (O.G. Costa, 1861) & 1 & & & & & & 3 & & & 2 \\
\hline Filogranula gracilis Langerhans (1884) & & & & & & 1 & & & 1 & 1 \\
\hline Janita fimbriata (Delle Chiaje, 1822) & & & & & 13 & 6 & 3 & 2 & 10 & 20 \\
\hline Spirobranchus polytrema (Philippi, 1844) & 5 & 6 & $\mathbf{1}$ & 4 & & & 5 & 2 & 2 & 3 \\
\hline Spirobranchus triqueter (Linnaeus, 1758) & 2 & & & & & & & & & 1 \\
\hline Hyalopomatus cf. variorugosus Ben-Eliahu \& Fiege, 1996 & 2 & & & & 6 & & & & & 6 \\
\hline Josephella marenzelleri Caullery \& Mesnil, 1856 & 42 & 18 & & 60 & $5+35$ & 140 & $16+20$ & $70+18$ & 60 & $35+35$ \\
\hline 'Protula tubularia' (Montagu, 1803) & 2 & & 3 & & $9+\mathbf{1}$ & $6+3$ & $12+2$ & & $8+6$ & $25+2$ \\
\hline Protula sp.1 & & & & & 2 & 12 & & 4 & & 8 \\
\hline Serpulinae sp. 1 & & & & & & & & 2 & 1 & \\
\hline \multicolumn{11}{|l|}{ Spirorbinae } \\
\hline Spirorbis cuneatus Gee J.M., 1964 & & 4 & & 5 & & & & & 3 & 3 \\
\hline Pileolaria heteropoma Zibrowius, 1968 & & 2 & & & & & & & & \\
\hline Pileolaria militaris Claparède, 1870 & & 1 & 1 & & & & & 3 & & \\
\hline Protolaeospira (Protolaeospira) striata (Quievreux, 1963) & & & 4 & & & & $4+6$ & 6 & & \\
\hline Vinearia koehleri (Caullery \& Mesnil, 1897) & & & & 3 & & & & 3 & 1 & \\
\hline Janua (Dexiospsira) pagenstecheri (Quatrefages, 1866) & & 2 & & & 2 & & 3 & & 3 & 3 \\
\hline Spirorbinae sp.1 & & 1 & & & 1 & & & & & \\
\hline Total number of specimens & 67 & 74 & 118 & 121 & 296 & 420 & 166 & 258 & 244 & 319 \\
\hline
\end{tabular}


consisted of 26 taxa (19 Serpulinae and 7 Spirorbinae), of which 18 were common in the two caves (15 Serpulinae and 3 Spirorbinae). The most widely distributed and abundant species were Semivermilia crenata, Josephella marenzelleri and Metavermilia multicristata, in all cases. The remaining taxa presented much lower abundances. Selected photographs of serpulid specimens are presented in Figure 2.

\section{Spatial patterns}

Serpulid abundance increased inwards in both caves (Table 3); however, this variability was significant only in Fara cave, for the living community $(\mathrm{df}=5$, Pseudo- $\mathrm{F}=3.5903, P<0.05)$, the thanatocoenosis $(\mathrm{df}=5$, Pseudo-F $=10.185, P<0.01)$, and the total community ( $\mathrm{df}=5$, Pseudo-F $=8.2601, P<$ o.01). The number of taxa and the Shannon-Wiener diversity index did not change significantly in either of the two caves. Higher numbers of taxa were recorded in all stations of Agios Vasilios cave compared with those of Fara cave (Table 3).

Multivariate resemblance analysis revealed three major groups of stations with similarity greater than $60 \%$, as shown in the MDS plot (Figure 3): (1) stations from the semidark sector of Fara cave ( $\mathrm{F}_{3}$ with $\left.\mathrm{FC} 1\right)$; (2) stations from the semi-dark sector of Agios Vasilios cave ( $\mathrm{VC}_{1}$ with $\mathrm{V}_{1}$ ); and (3) stations from the dark sectors of both caves ( $\mathrm{FC}_{2}, \mathrm{~F}_{4}$,
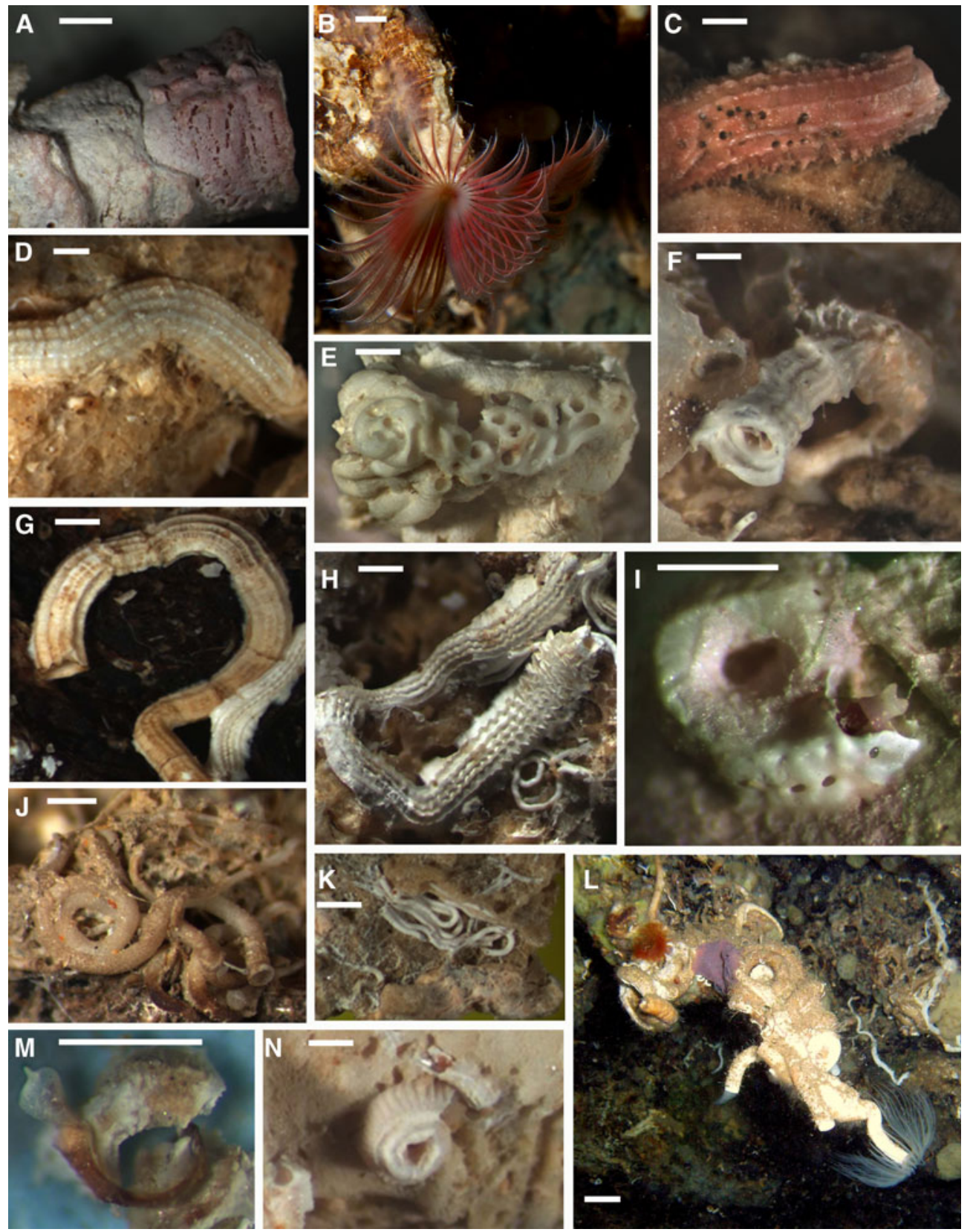

Fig. 2. Photographs of serpulid specimens from different stations of the studied marine caves (in parentheses): (A) Serpula cavernicola (V1); (B) 'Serpula vermicularis' (Fara cave); (C) Serpula vermicularis f. echinata (V1); (D) Serpula concharum (FC2); (E) Spiraserpula massiliensis (VC2); (F) Vermiliopsis labiata (V1); (G) Metavermilia multicristata (F4); (H) Semivermilia crenata (V2); (I) Spirobranchus polytrema (FC1); (J) Hyalopomatus cf. variorugosus (V2); (K)

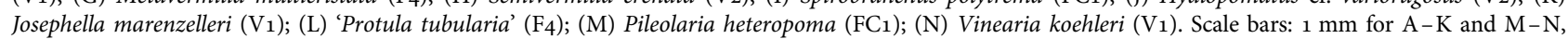
$1 \mathrm{~cm}$ for L. Photos by R. Sanfilippo (A, C-K, M-N), T. Dailianis (B) and V. Gerovasileiou (L). 
Table 3. Number of taxa $(\mathrm{S})$, mean abundance $(\mathrm{N})$ and Shannon-Wiener diversity $\left(\mathrm{H}^{\prime}\right)$ per sampling station for the total and living communities and for the thanatocoenoses, respectively.

\begin{tabular}{|c|c|c|c|c|c|c|c|c|c|}
\hline \multirow[t]{2}{*}{ Stations } & \multicolumn{3}{|c|}{ Total community } & \multicolumn{3}{|c|}{$\begin{array}{l}\text { Living } \\
\text { community }\end{array}$} & \multicolumn{3}{|c|}{ Thanatocoenosis } \\
\hline & $S$ & $N$ & $\boldsymbol{H}^{\prime}$ & $S$ & $N$ & $\boldsymbol{H}^{\prime}$ & $S$ & $N$ & $\boldsymbol{H}^{\prime}$ \\
\hline $\mathrm{F}_{1}$ & 10 & 22.3 & 1.444 & 2 & 15.3 & 0.295 & 8 & 7 & 1.976 \\
\hline $\mathrm{FC}_{1}$ & 11 & 24.7 & 1.792 & 2 & 2 & 0.693 & 9 & 22.7 & 1.597 \\
\hline $\mathrm{F}_{2}$ & 8 & 38.7 & 1.09 & 5 & $7 \cdot 3$ & 1.327 & 5 & 31.3 & 0.903 \\
\hline $\mathrm{F}_{3}$ & 7 & 39.7 & 1.331 & 1 & 1.3 & o & 6 & 38.3 & 1.225 \\
\hline $\mathrm{FC}_{2}$ & 11 & 113 & 1.379 & 4 & $17 \cdot 3$ & 0.909 & 11 & 93 & 1.23 \\
\hline $\mathrm{F}_{4}$ & 10 & 140 & 1.417 & 2 & 2.3 & 0.683 & 10 & 137.7 & 1.391 \\
\hline $\mathrm{V}_{1}$ & 15 & 85.7 & 1.752 & 7 & 12.7 & 1.593 & 11 & 73 & 1.563 \\
\hline $\mathrm{VC}_{1}$ & 12 & $54 \cdot 3$ & 1.582 & 5 & $14 \cdot 3$ & 1.229 & 10 & 40 & 1.472 \\
\hline $\mathrm{VC}_{2}$ & 14 & 81 & 1.874 & 4 & 24 & 0.624 & 12 & 55 & 1.623 \\
\hline $\mathrm{V}_{2}$ & 16 & 106.3 & 2.151 & 3 & 14 & 0.55 & 16 & 92.3 & 2.201 \\
\hline
\end{tabular}

$\mathrm{VC}_{2}$ and $\mathrm{V}_{2}$ ), regardless of the position on the cave walls. The two outermost stations of Fara cave, F1 and F2, differed from the above groups. According to the results of SIMPER analysis, the taxa which contributed by $60 \%$ to the similarity of samples within the above groups were respectively (in order of appearance): (1) S. crenata, J. marenzelleri and Spirobranchus polytrema; (2) S. crenata, J. marenzelleri, Protolaeospira (P.) striata and Serpula vermicularis f. echinata; (3) S. crenata, J. marenzelleri, M. multicristata and 'Protula tubularia'. On the other hand, the taxa which contributed to $60 \%$ of the dissimilarity between the above groups could be categorized as follows: (a) taxa with higher abundance in the inner dark cave sectors (e.g. Vermiliopsis labiata, 'P. tubularia', Spiraserpula massiliensis and M. multicristata); (b) taxa recorded exclusively in the dark cave sectors (Semivermilia pomatostegoides); (c) taxa with higher abundance in the semidark cave sectors (e.g. P. striata).

\section{Ecological groups}

Sciaphilic/coralligenous serpulids prevailed in terms of number of taxa (8) in both caves, followed by deep-water (8), shallow-shelf (5), shelf (3), cave (2) and unplaced taxa (Table 4 ). The same order was recorded with regards to abundance. The abundance of the three first groups increased towards the dark interior of both caves (Figure 4). However,

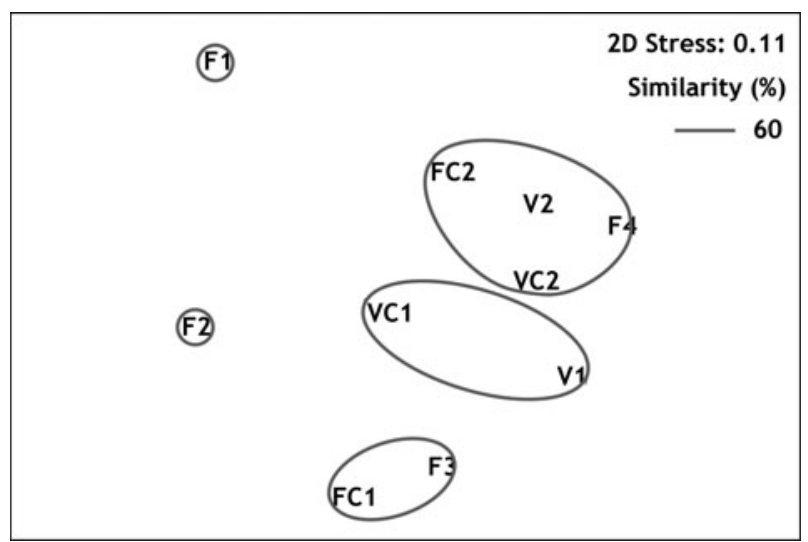

Fig. 3. Resemblance of sampling stations demonstrated in MDS plot.
Table 4. Assignment of the serpulid taxa recorded in the studied caves to ecological groups according to the classification scheme by Rosso et al. (2013) and newly acquired data.

\begin{tabular}{lc}
\hline Ecological groups & Taxa \\
\hline $\begin{array}{l}\text { Sciaphilic and/or } \\
\text { coralligenous taxa }\end{array}$ & $\begin{array}{c}\text { Filogranula calyculata, Josephella marenzelleri, } \\
\text { Metavermilia multicristata, Protolaeospira } \\
(P .) \text { striata, Semivermilia crenata, Serpula } \\
\text { concharum (deep form), Vermiliopsis } \\
\text { labiata, Vinearia koelheri }\end{array}$ \\
Filogranula gracilis, Hyalopomatus cf. \\
variorugosus, Janita fimbriata, 'Protula \\
tubularia', Semivermilia pomatostegoides \\
Serpula concharum, Spirobranchus polytrema, \\
S. triqueter, Janua (Dexiospira) \\
pagenstecheri, Pileolaria heteropoma \\
Serpula vermicularis f. echinata, Spirorbis \\
cuneatus, Pileolaria militaris \\
Cave taxa & Serpula cavernicola, Spiraserpula massiliensis \\
Unplaced taxa & Protula sp.1, Serpulinae sp.1, 'Serpula \\
& vermicularis', Spirorbinae sp.1
\end{tabular}

variability was significant only in Fara cave, for the sciaphilic/coralligenous $(\mathrm{df}=5$, Pseudo- $\mathrm{F}=9.0973, P<0.01)$ and deep-water groups $(\mathrm{df}=5$, Pseudo-F $=3.0735, P<0.01)$.

\section{Bioconstructions and aggregates}

Serpulids were more abundant in the innermost dark sectors where the rock was only partially covered by serpulids and coated by diffuse black oxide crusts (Figure $5 \mathrm{~A}$ ). They were mostly found as isolated tubes, but in the innermost sectors of the caves some taxa aggregated to form three-dimensional structures. 'Giant' isolated tubes (up to $1 \mathrm{~m}$ long) possibly belonging to the genus Protula (observed in situ) were among the largest encrusters in the inner dark edge of Agios Vasilios cave. Some ' $P$. tubularia' specimens were locally aligned (Figure $5 \mathrm{~B}$ ), or aggregated, forming bioconstructions, often associated with nodular bryozoan concretions

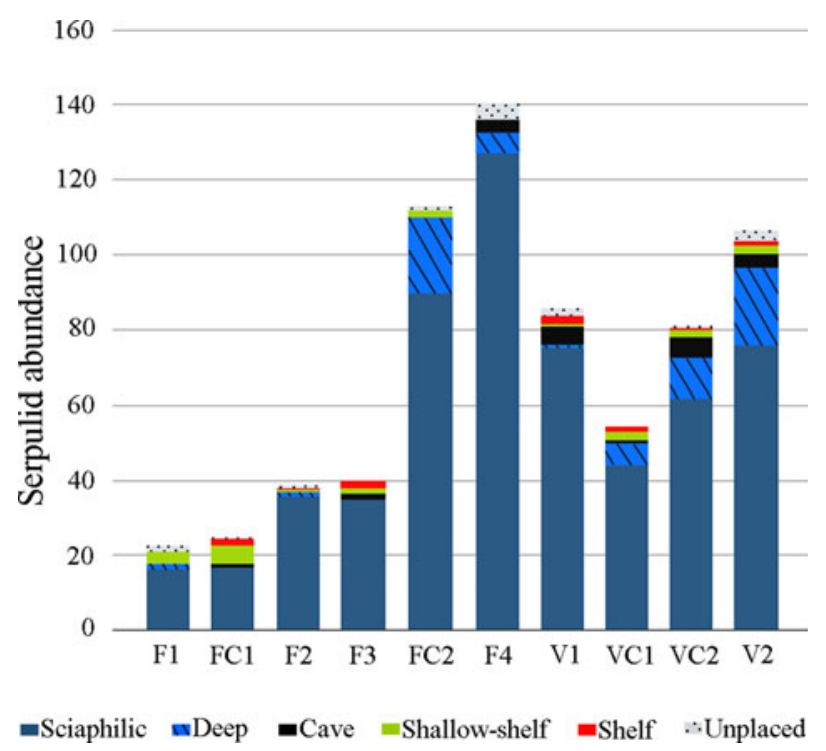

Fig. 4. Contribution of the different ecological groups to the abundance of serpulids in the sampling stations of the studied caves. 
(Figure $5 \mathrm{C}$ ). Thick crusts of tubes, resulting from the superimposition of successive generations of different serpulid taxa, were obvious at places (Figure $5 \mathrm{D}$ ).

Bioconstructions of 'P. tubularia' had two forms: (1) coiled 'doughnuts' of tubes (Figure 6A), up to $6 \mathrm{~cm}$ in diameter, resulting from the superimposition of tube whorls strictly adhering to each other (Figure 6B), sometimes presenting straight tube end (the diameter of tube whorls was often progressively increasing); and (2) plait-like aggregates, $\sim 8 \mathrm{~cm}$ high and $4 \mathrm{~cm}$ wide, formed by irregularly coiled and intermingled tubes (Figure 6C-E). The doughnut-like formations were larger and more frequent inwards (Figure 6F). The plaitlike structures were hanging from the ceilings and projected obliquely from the walls in inner semi-dark and dark cave sectors (Figure 6G).

The microserpulid J. marenzelleri locally formed mm-thick crusts of intermingled tubes, resulting in three-dimensional intricate nets. They occurred in samples from the semi-dark and dark cave communities, coating the surface of bryozoan concretions and Protula tubes, and filling small cavities (Figure 6H). These Josephella 'nets' were locally recrystallized, with secondary large crystals substituting the tube walls and filling spaces between tubes (Figure 6K).

\section{DISCUSSION}

The results of the present study showed that the surveyed Aegean marine caves host a rich serpulid fauna (14 living and 27 dead taxa), comparable to that from marine caves in the western and central Mediterranean Sea, which had been thoroughly studied for their serpulid diversity; notable examples include: Bagaud cave (19 living taxa), in South France (Harmelin et al., 2003); Mitigliano (27 living taxa) and the semi-submerged Accademia (2 living and 20 dead taxa) caves in the Tyrrhenian Sea (Belloni \& Bianchi, 1982; Bianchi, 1985; Balduzzi et al., 1989; Di Geronimo et al., 1993; Rosso et al., 2013); Mazzere, Gymnasium, and Granchi caves (13 living and 32 dead taxa) in the Ionian Sea, Sicily (Rosso et al., 2013); the semi-submerged Ciolo cave (20 living) in the Ionian Sea, southern Apulia (Denitto \& Licciano, 2006).

The species Hyalopomatus cf. variorugosus is reported for the first time from the marine cave habitat. This species had been reported from bathyal bottoms of other Mediterranean regions, with living and dead specimens (Ben-Eliahu \& Fiege, 1996; Sanfilippo, 1998, 2009; Rosso et al., 2010), and from Pleistocene bathyal deposits of southern Italy (Di Geronimo et al., 1997). The remaining taxa have already been reported from other marine caves in the Mediterranean Sea (Di Geronimo et al., 1993; Taddei-Ruggiero et al., 1996; Bianchi \& Sanfilippo, 2003; Rosso et al., 2013). Serpulid communities from caves located at comparable depths along the Tyrrhenian and Ionian coasts of Sicily had a similar structure, with the species Semivermilia crenata and Josephella marenzelleri dominating (Rosso et al., 2013). Interestingly, some taxa (i.e. Serpula vermicularis f. echinata, Filogranula calyculata, $H$. cf. variorugosus, Serpulinae sp.1 and Spirorbinae sp.1) found in the studied Aegean caves were absent from marine caves of Sicily. On the other hand, several species that are known to be typical cave-dwellers (Rosso et al., 2013 and references therein) e.g.
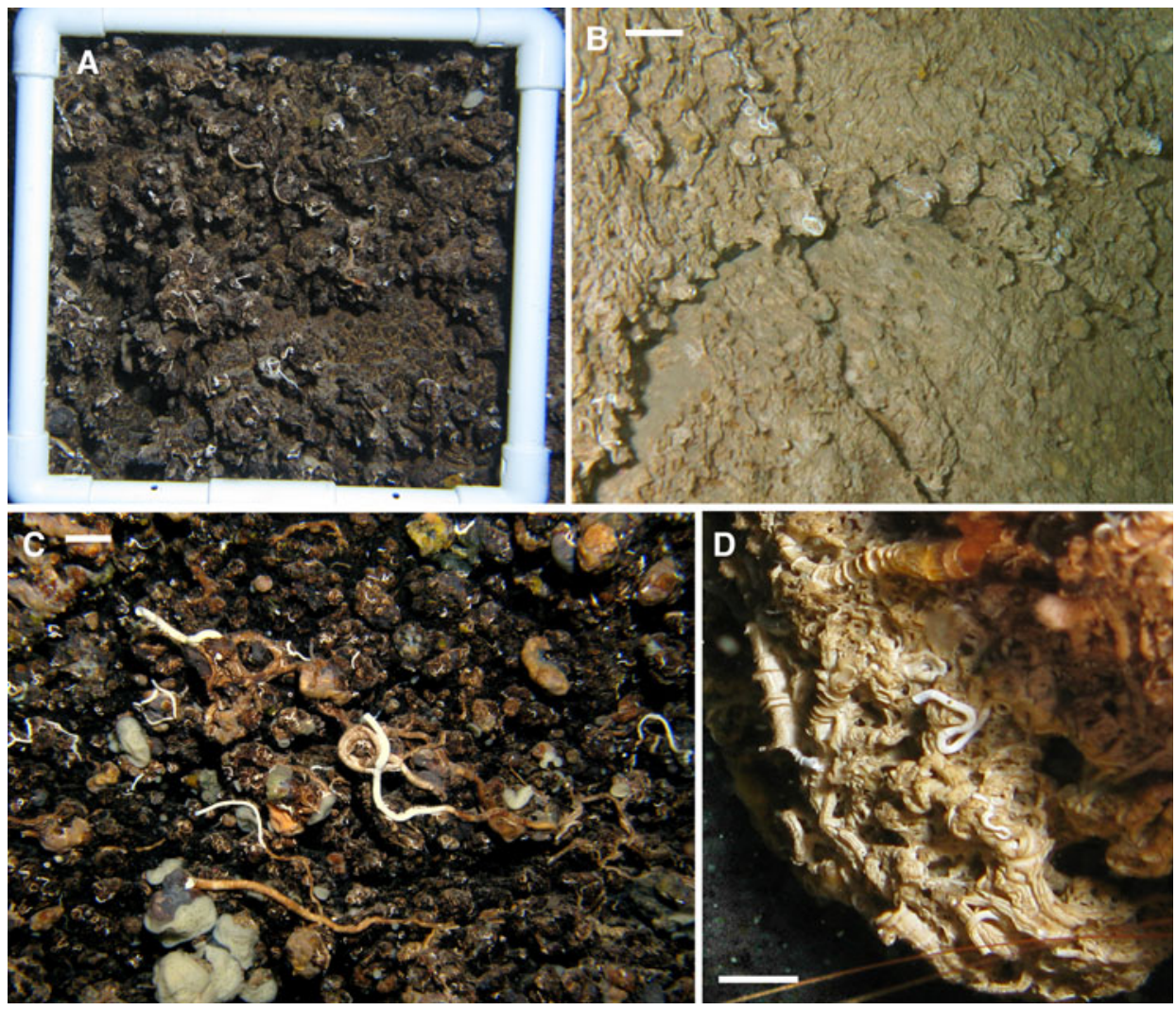

Fig. 5. (A) Wall of Fara cave from the dark zone, partially covered by different species of serpulids and coated by diffuse black oxide crusts $(20 \times 20 \mathrm{~cm}$ sampled surface F4, $30 \mathrm{~m}$ from the entrance); (B) Aligned biostalactites along a fissure of the right wall in Agios Vasilios cave (20 m from the entrance); (C) Serpulid bioconstructions associated with nodular bryozoan concretions in the dark zone of Fara cave ( $25 \mathrm{~m}$ from the entrance); (D) Thick crusts of superimposed tubes formed by subsequent serpulid generations in Agios Vasilios cave (20 m from the entrance). Scale bars: $5 \mathrm{~cm}$ for B, $1 \mathrm{~cm}$ for C, D. Photos by V. Gerovasileiou. 


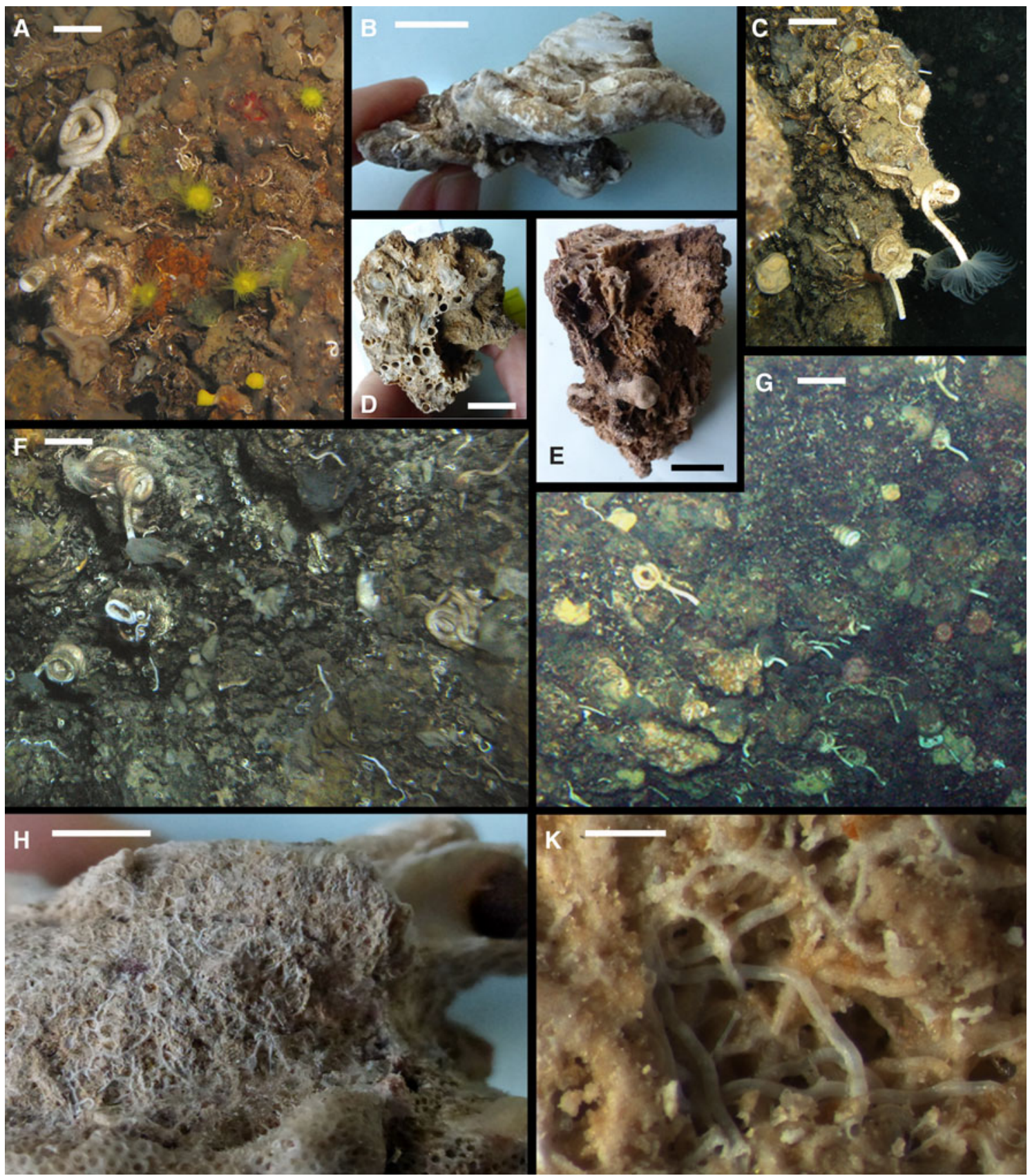

Fig. 6. (A) Coiled 'doughnuts' of tubes belonging to the large-sized serpulid 'Protula tubularia' ( $15 \mathrm{~m}$ from the entrance, Agios Vasilios cave); (B) A doughnut-like Protula bioconstruction, showing several tube whorls of increasing diameter $(5 \mathrm{~m}$ from the entrance, Agios Vasilios cave); (C) Biostalactites built by aggregated individuals of the serpulid 'P. tubularia' ( $25 \mathrm{~m}$ from the entrance, Fara cave); (D, E) Subconical biostalactite formed by aggregated Protula tubes and cemented micrite: cross section and longitudinal view (32 $\mathrm{m}$ from the entrance, Fara cave); (F) Wall in the dark zone of Fara cave, covered with doughnut-like formations ( $30 \mathrm{~m}$ from the entrance); (G) Cave wall with densely spaced biostalactites $\left(\sim 10\right.$ formations $\left./ \mathrm{cm}^{2}\right)$, obliquely projecting towards the center of Fara cave $(20-30 \mathrm{~m}$ from the entrance); (H) Intricate mm-thick tube nets formed by the microserpulid Josephella marenzelleri associated with bryozoans, developing on a doughnut-like tube of Protula (sample V2, Agios Vasilios cave); (K) Detail of $\mathrm{H}$ showing locally recrystallized micrite sediments between tubes. Scale bars: $1 \mathrm{~cm}$ for figures A-G, $5 \mathrm{~mm}$ for H, $1 \mathrm{~mm}$ for K. Photos by V. Gerovasileiou (A and F), R. Sanfilippo (B, D-E, H-K) and M. Sini (C and G).

Filogranula annulata, Placostegus tridentatus, P. crystallinus, Semivermilia cribrata, Simplaria pseudomilitaris, Spirorbis marioni and Vermiliopsis monodiscus, were not found among the scraped samples. These differences can be attributed to the high biogeographic heterogeneity of sessile taxa in Mediterranean marine caves (Gerovasileiou \& Voultsiadou, 2012) coupled with the locally patchy distribution of taxa inside caves (Harmelin, 1986, 1997; Rosso et al., 2013) or mere sampling biases. For instance, the species $P$. tridentatus and $V$. monodiscus were recently recorded as infauna in the canals of the sponges Agelas oroides and Aplysina aerophoba in the studied Aegean caves (Gerovasileiou et al., 2016b). The majority of taxa recorded in this study (18 taxa, 67\%), are also new elements for the marine cave fauna of the Aegean Sea, according to the most recent biodiversity census in this habitat type (Gerovasileiou et al., 2015).

Two of the species identified in this study, $H$. cf. variorugosus and Serpula cavernicola are new records for the serpulid 
fauna of the Aegean ecoregion (Arvanitidis, 2000; Ben Eliahu \& ten Hove, 2011; Çinar et al., 2014). The latter species is a typical cave-dweller, restricted to dark sectors of marine caves (Sanfilippo \& Mòllica, 2000). It has been rarely reported from the Ionian and Tyrrhenian seas, the Straits of Gibraltar and the southern coasts of Portugal in the Atlantic Ocean, usually found as empty tubes (Fassari \& Mòllica, 1991; Taddei-Ruggiero et al., 1996; Sanfilippo \& Mòllica, 2000; Rosso et al., 2013). In the studied caves, only dead specimens of $S$. cavernicola were found in several stations (Table 1 ).

It has been suggested that marine caves function as 'islands', supporting isolated populations of sessile taxa (Muricy et al., 1996), which often exhibit morphological adaptations to the local environmental conditions (Harmelin et al., 1985). Furthermore, several cave-exclusive species have been recorded from only one or very few caves (Gerovasileiou \& Voultsiadou, 2012; Gerovasileiou et al., 2016a). In this respect, a number of serpulid taxa recorded in the studied Aegean caves deserve further study from the taxonomic point of view (morphological and molecular). These include the serpulids identified only at higher-than-species taxonomic levels (i.e. Protula sp.1, Serpulinae sp.1, Spirorbinae sp.1) as well as the species ' $P$. tubularia' and 'S. vermicularis', whose cosmopolitan distribution has been questioned (Kupriyanova \& Jirkov, 1997; ten Hove \& Kupriyanova, 2009). Distinct forms of certain taxa (i.e. S. vermicularis f. echinata and S. concharum (deep form)), which belong to different ecological groups (Table 4), were found in the deeper Agios Vasilios cave. Targeted study of the abovementioned taxa would also be interesting from an ecological and taxonomic point of view.

The results of the multivariate resemblance analysis, coupled with those of the distribution of the different ecological groups across the studied caves, revealed that the structure of the serpulid community in the inner zone differs from that of the more heterogeneous outer semi-dark sectors. Specifically, the abundance of sciaphilic, deep-water and cave taxa increased inwards, following the environmental gradients such as the loss of light and the increasing water confinement (Balduzzi et al., 1989; Bianchi \& Morri, 1994; Sanfilippo et al., 2015). This variability was more conspicuous in Fara cave and is possibly related to the higher level of confinement in this cave, as it is characterized by a more elongated shape and a narrower cross-sectional area, compared with the wider and less confined Agios Vasilios cave (Gerovasileiou et al., 2013a; Gerovasileiou \& Voultsiadou, 2016). The considerably higher percentage of deep-water taxa in the inner dark cave sectors is in accordance with the hypothesis that dark caves form 'deep-sea mesocosms' in the shallow littoral zone, presenting faunal affinities to the deep-sea (Zibrowius, 1971; Vacelet et al., 1994; Harmelin \& Vacelet, 1997; Martínez et al., 2013).

Serpulid bioconstructions in the form of 'coiled doughnuts' by ' $P$. tubularia' seem to be unknown from other Mediterranean caves and deserve to be further investigated. On the other hand, the plait-like aggregates are similar to biostalactites currently being studied in a cave in Cyprus (Guido et al., unpublished data) and to those found in other caves at comparable depths in the Apulian (Onorato et al., 2003; Belmonte et al., 2009) and Sicilian coasts of Italy, central Mediterranean (Guido et al., 2013, 2016a; Sanfilippo et al., 2015). These biostalactites consist of skeletonized invertebrates and syndepositional-cemented micrite deposited in situ through microbial metabolic activity (Guido et al., 2012, 2013, 2014, 2016b). The aggregation of
Protula specimens forming this type of biostalactite seems to be influenced by the local salinity gradients induced by the dilution of continental water inflows through fractures in the surrounding rocks (Guido et al., 2014; Sanfilippo et al., 2015). A similar process could be responsible for the formation of the numerous biostalactites aligned along fissures of the Agios Vasilios cave.

In conclusion, the present study provided a first record of the marine cave serpulid fauna in the Aegean Sea identifying basic community patterns and interesting faunal affinities with other habitats as well as new faunal element sand forms of bioconstructions for the Mediterranean marine cave habitat. The results of the present study suggest that several aspects of the marine cave communities are still poorly known and deserve to be investigated.

\section{ACKNOWLEDGEMENTS}

The authors would like to thank Eleni Voultsiadou, Alejandro Martínez and an anonymous reviewer for their constructive comments, Maria Sini and Thanos Dailianis for providing underwater photographs and Dimitris Poursanidis for designing the map of the study area.

\section{FINANCIAL SUPPDRT}

This study was supported by the Research Funding Programme 'Heracleitus II: Investing in knowledge society' (EU and Greek national funds). VG also benefited from 'Alexander S. Onassis Public Benefit Foundation' fellowship for postgraduate studies. This is contribution number 423 of the Catania Palaeontological Research Group.

\section{REFERENCES}

Antonioli F., Silenzi S. and Frisia S. (2001) Tyrrhenian Holocene paleoclimate trends from spelean serpulids. Quaternary Science Reviews 20, $1661-1670$.

Arvanitidis C. (2000) Polychaete fauna of the Aegean Sea: inventory and new information. Bulletin of Marine Science 66, 73-96.

Bailey J.H. (1969) Spirorbinae (Polychaeta: Serpulidae) from Chios (Aegean Sea). Zoological Journal of the Linnean Society 48, 363-385.

Balduzzi A., Bianchi C.N., Boero F., Cattaneo-Vietti R., Pansini M. and Sarà M. (1989) The suspension-feeder communities of a Mediterranean Sea cave. Scientia Marina 53, 387-395.

Belloni S. and Bianchi C.N. (1982) Policheti d'alcune grotte marine della Penisola Sorrentina (Golfo di Napoli). Bollettino dei Musei e degli Istituti Biologici dell'Università di Genova 50(Suppl.), 118-127.

Belmonte G., Ingrosso G., Poto M., Quarta G., D'Elia M., Onorato R. and Calcagnile L. (2009) Biogenic stalactites in submarine caves at the Cape of Otranto (SE Italy): dating and hypothesis on their formation. Marine Ecology 30, 376-382.

Ben-Eliahu M.N. and Fiege D. (1996) Serpulid tube-worms (Annelida: Polychaeta) of the central and eastern Mediterranean with particular attention to the Levant Basin. Senckenbergiana Maritima 28, 1-51.

Ben-Eliahu M.N. and ten Hove H.A. (2011) Serpulidae (Annelida: Polychaeta) from the Suez Canal from a Lessepsian migration perspective (a monograph). Zootaxa 2848, 1-147. 
Bianchi C.N. (1985) Structure trophique du peuplement annéllidien dans quelques grottes sous-marines méditerranéennes. Rapports et Procès-verbaux des Réunions. Commission International pour l'Exploration Scientifique de la Mer Méditerranée, Monaco 29, 147148.

Bianchi C.N. and Morri C. (1994) Studio biologico comparativo di alcune grotte marine sommerse: definizione di una scala di confinamento. Memorie Istituto Italiano di Speleologia serie 2, 107-123.

Bianchi C.N. and Morri C. (200o) Serpuloidea (Annelida: Polychaeta) from Milos, an island in the Aegean Sea with submarine hydrothermism. Journal of the Marine Biological Association of the United Kingdom 80, 259-269.

Bianchi C.N., Morri C., Chiantore M., Montefalcone M., Parravicini V. and Rovere A. (2012) Mediterranean Sea biodiversity between the legacy from the past and a future of change. In Stambler N. (ed.) Life in the Mediterranean Sea: a look at habitat changes. New York, NY: Nova Science Publishers, pp. 1-55.

Bianchi C.N. and Sanfilippo R. (2003) Policheti Serpuloidei (a cura di Cicogna F., Bianchi C.N., Ferrari G. and Forti P. (eds) Grotte marine: cinquant'anni di ricerca in Italia. Rome: Ministero dell'Ambiente e della Tutela del Territorio, pp. 175-185 (+ bibliografia pp. 459-505).

Bussotti S., Terlizzi A., Fraschetti S., Belmonte G. and Boero F. (2006) Spatial and temporal variability of sessile benthos in shallow Mediterranean marine caves. Marine Ecology Progress Series 325, 109-119.

Chintiroglou C. and Koukouras A. (1992) A population of the sea anemone Anemonia viridis (Forskal, 1775) and its associated flora and fauna in the North Aegean Sea. Internationale Revue der gesamten Hydrobiologie und Hydrographie 77, 483-495.

Çinar M.E., Dağli E. and Kurt Şahin G. (2014) Checklist of Annelida from the coasts of Turkey. Turkish Journal of Zoology 38, 734-764.

Clarke K.R. and Gorley R.N. (2006) PRIMER v6: user manual/tutorial. Plymouth: PRIMER-E.

Denitto F. and Licciano M. (2006) Recruitment of Serpuloidea (Annelida: Polychaeta) in a marine cave of the Ionian Sea (Italy, central Mediterranean). Journal of the Marine Biological Association of the United Kingdom 86, 1373-1380.

Di Geronimo I., D'Atri A., La Perna R., Rosso A., Sanfilippo R. and Violanti D. (1997) The Pleistocene bathyal section of Arch (Southern Italy). Bollettino della Società Paleontologica Italiana 36, $189-212$.

Di Geronimo I., LaPerna R., Rosso A. and Sanfilippo R. (1993) Popolamento e tanatocenosi bentonica della Grotta dell'Accademia (Ustica, Mar Tirreno meridionale). Il Naturalista Siciliano s.4, XVII, $45-63$.

Fassari G. and Mòllica E. (1991) Una nuova specie di Serpulidae (Annelida Polychaeta) di grotta. Animalia 18, 261-267.

Gerovasileiou V., Chintiroglou C.C., Konstantinou D. and Voultsiadou E. (2016b) Sponges as 'living hotels' in Mediterranean marine caves. Scientia Marina 80, 279-289.

Gerovasileiou V., Chintiroglou C.C., Vafidis D., Koutsoubas D., Sini M., Dailianis T., Issaris Y., Akritopoulou E., Dimarchopoulou D. and Voultsiadou E. (2015) Census of biodiversity in marine caves of the Eastern Mediterranean Sea. Mediterranean Marine Science 16, 245-265.

Gerovasileiou V., Koutsoubas D. and Voultsiadou E. (2014) Spatial heterogeneity of benthic communities in a marine cave off Lesvos Island (Aegean Sea). In Langar H., Bouafif C. and Ouerghi A. (eds) Proceedings of the 1st Mediterranean Symposium on the
Conservation of Dark Habitats, Portorož, Slovenia, 27-31 October 2014. Tunis: RAC/SPA, pp. 69-70.

Gerovasileiou V., Martínez A., Álvarez F., Boxshall G., Humphreys W.F., Jaume D., Becking L.E., Muricy G., van Hengstum P.J., Dekeyzer S., Decock W., Vanhoorne B., Vandepitte L., Bailly N. and Iliffe T.M. (2016a) World Register of marine Cave Species (WoRCS): a new thematic species database for marine and anchialine cave biodiversity. Research Ideas and Outcomes 2, e10451. doi: 10.3897/rio.2.e10451

Gerovasileiou V., Trygonis V., Sini M., Koutsoubas D. and Voultsiadou E. (2013a) Three-dimensional mapping of marine caves using a handheld echosounder. Marine Ecology Progress Series 486, 13-22.

Gerovasileiou V., Vafidis D., Koutsoubas D. and Voultsiadou E. (2013b) Spatial heterogeneity of sessile benthos in a submerged cave of the eastern Mediterranean. Rapports et Proces-verbaux des Reunions. Commission International pour l'Exploration Scientifique del la Mer Méditerranée 40, 880.

Gerovasileiou V. and Voultsiadou E. (2012) Marine caves of the Mediterranean Sea: a sponge biodiversity reservoir within a biodiversity hotspot. PLoS ONE 7, e39873.

Gerovasileiou V. and Voultsiadou E. (2016) Sponge diversity gradients in marine caves of the eastern Mediterranean. Journal of the Marine Biological Association of the United Kingdom 96, 407-416.

Guido A., Heindel K., Birgel D., Rosso A., Mastandrea A., Sanfilippo R., Russo F. and Peckmann J. (2013) Pendant bioconstructions cemented by microbial carbonate in submerged marine caves (Holocene, SE Sicily). Palaeogeography, Palaeoclimatology, Palaeoecology 388, 166-180.

Guido A., Mastandrea A., Rosso A., Sanfilippo R. and Russo F. (2012) Micrite precipitation induced by sulphate reducing bacteria in serpulid bioconstructions from submarine caves (Syracuse, Sicily). Rendiconti Online della Società Geologica Italiana 21, 933-934.

Guido A., Mastandrea A., Rosso A., Sanfilippo R., Tosti F., Riding R. and Russo F. (2014) Commensal symbiosis between agglutinated polychaetes and sulfate reducing bacteria. Geobiology 12, 26-275.

Guido A., Rosso A., Sanfilippo R., Russo F. and Mastandrea A. (2016a) Submarine caves: a laboratory for geomicrobiology studies. Rendiconti Online della Società Geologica Italiana 38, 62-64.

Guido A., Rosso A., Sanfilippo R., Russo F. and Mastandrea A. (2016b) Frutexites from microbial/metazoan bioconstructions of recent and Pleistocene marine caves (Sicily, Italy). Palaeogeography, Palaeoclimatology, Palaeoecology 453, 127-138.

Harmelin J.-G. (1985) Organisation spatiale des communautés sessiles des grottes sous-marines de Méditerranée. Rapports et Procès-verbaux des Réunions. Commission International pour l'Exploration Scientifique de la Mer Méditerranée, Monaco 28, 259-261.

Harmelin J.-G. (1986) Patterns in the distribution of bryozoans in the Mediterranean marine caves. Stygologia 2, 10-25.

Harmelin J.-G. (1997) Diversity of bryozoans in a Mediterranean sublittoral cave with bathyal-like conditions: role of dispersal processes and local factors. Marine Ecology Progress Series 153, 139-152.

Harmelin J.G., Boury-Esnault N., Fichez R., Vacelet J. and Zibrowius H. (2003) Peuplement de la grotte sous-marine de l'île de Bagaud (Parc national de Port-Cros, France, Méditerranée). Travaux scientifiques $d u$ Parc national de Port-Cros 19, 117-134.

Harmelin J.-G. and Vacelet J. (1997) Clues to deep-sea biodiversity in nearshore caves. Vie Milieu 47, 351-354.

Harmelin J.-G., Vacelet J. and Vasseur P. (1985) Les grottes sousmarines obscures: un milieu extrême et un remarquable biotope refuge. Téthys 11, 214-229. 
ten Hove H.A., and Kupriyanova E. (2009) Taxonomy of Serpulidae (Annelida, Polychaeta): the state of affairs. Zootaxa 2036, 1-126.

Katsikatsos G., Matarangas D., Migiros G. and Triantaphyllis M. (1982) The geological structure of Lesvos Island. Report IGME, $95 \mathrm{pp}$.

Knight-Jones P., Knight-Jones E.W. and Ergen Z. (1991) Sabelliform polychaetes, mostly from Turkey's Aegean Coast. Journal of Natural History 25, 837-858.

Koçak F., Ergen Z. and Cinar M.E. (1999) Fouling organisms and thei developments in a polluted and an unpolluted marina in the Aegean Sea (Turkey). Ophelia 50, 1-20.

Kupriyanova E.K. and Jirkov I.A. (1997) Serpulidae (Annelida, Polychaeta) of the Arctic Ocean. Sarsia 82, 203-236.

Macintyre I.G., Rützler K., Norris J.N. and Fauchald K. (1982) A submarine cave near Columbus Cay, Belize: a bizarre cryptic habitat. Smithsonian Contributions to the Marine Sciences 12, 12-141.

Martínez A., Di Domenico M. and Worsaae K. (2013) Evolution of cave Axiokebuita and Speleobregma (Scalibregmatidae, Annelida). Zoologica Scripta 42, 623-636.

Muricy G., Solé-Cava A.M., Thorpe J.P. and Boury-Esnault N. (1996) Genetic evidence for extensive cryptic speciation in the subtidal sponge Plakinatrilopha (Porifera: Demospongiae: Homoscleromorpha) from the Western Mediterranean. Marine Ecology Progress Series 138, $181-187$.

Onorato R., Forti P., Belmonte G., Costantini A. and Poto M. (2003) La grotta sottomarina lu Lampiùne: novità esplorative e prime indagini ecologiche. Thalassia Salentina 26, 55-64.

Quarta G., D'Elia M., Calcagnile L., Belmonte G. and Ingrosso G. (2010) Reconstructing the formation mechanism of submarine biogenic stalactites: the contribution of AMS. Nuclear Instruments and Methods in Physics Research B 268, 1244-1247.

Rosso A., Sanfilippo R., Taddei-Ruggiero E. and Di Martino E. (2013) Faunas and ecological groups of Serpuloidea, Bryozoa and Brachiopoda from submarine caves in Sicily. Bollettino della Società Paleontologica Italiana 52, 167-176.

Rosso A., Vertino A., Di Geronimo I., Sanfilippo R., Sciuto F., Di Geronimo R., Violanti D., Corselli C., Taviani M., Mastrototaro F. and Tursi A. (2010) Hard and soft-bottom thanatofacies from the Santa Maria di Leuca deep-water coral province, Mediterranean. Deep Sea Research II 57, 360-379.
Sanfilippo R. (1998) Tube morphology and structure of the bathyal Mediterranean serpulid Hyalopomatus variorugosus Ben-Eliahu \& Fiege, 1996 (Annelida, Polychaeta). Rivista italiana di Paleontologia e Stratigrafia 104, 131-138.

Sanfilippo R. (2009) New species of Hyalopomatus Marenzeller, 1878 (Annelida, Polychaeta, Serpulidae) from Recent Mediterranean deepwater coral mounds and comments on some congeners. Zoosystema $31,147-161$

Sanfilippo R. and Mòllica E. (200o) Serpula cavernicola Fassari \& Mollica, 1991 (Annelida Polychaeta): diagnostic features of the tubes and new Mediterranean records. Marine Life 10, 27-32.

Sanfilippo R., Rosso A., Guido A., Mastandrea A., Russo F., Ryding R. and Taddei-Ruggiero E. (2015) Metazooan/microbial biostalactites from modern submarine caves in the Mediterranean Sea. Marine Ecology 36, 1277-1293.

Taddei-Ruggiero E., Annunziata G., Rosso A. and Sanfilippo R. (1996) Il benthos della Grotta sottomarina dell'Isca (Penisola Sorrentina): evidenze faunistiche della sua evoluzione recente. VII Congresso Nazionale Società Italiana Ecologia, Napoli 17, 329-332.

Vacelet J., Boury-Esnault N. and Harmelin J.-G. (1994) Hexactinellid cave, a unique deep-sea habitat in the scuba zone. Deep-Sea Research I 41, 965-973.

Zibrowius H. (1968) Étude morphologique, systématique et écologique des Serpulidae (Annelida Polychaeta) de la région de Marseille (provenant essentiellement des grottes sous-marines). Recueil des Travaux de la Station Marine d'Endoume 43, 81-252.

and

Zibrowius H. (1971) Remarques sur la faune sessile des grottes sousmarines et de l'étage bathyal en Méditerranée. Rapports Commission Internationale mer Méditerranéenne 20, 243-245.

\section{Correspondence should be addressed to:} R. Sanfilippo Department of Biological, Geological and Environmental Sciences, University of Catania, Corso Italia, 57, I-95129 Catania, Italy email: sanfiros@unict.it 